\title{
The Effect of Customer Relationship Management on Market Performance of Selected Private Banks in Nekemte Town
}

\author{
Desalegn Bulti ${ }^{1} \quad$ Zemenu Fekede ${ }^{2}$ \\ 1.Lecturer, Department of Management, Mettu University, Mettu, Ethiopia \\ 2.Lecturer, Department of Accounting and Finance, Mettu University, Mettu, Ethiopia
}

\begin{abstract}
The specific objective of the study was to examine the effect of customer orientation on market performance, effects of Customer Knowledge management on market performance, Effects technology based CRM on market performance and effects of CRM Organization on market performance. The study adopted both descriptive and explanatory research design. The study targeted employees in the selected private banks. Purposive sampling technique was used to select private banks. Data analyzed using Statistical Package for Social Sciences (SPSS). Data presented using tables and figures. Correlation and multiple regression analysis were used to establish the relationship between the study variables. The study found that customer relationship management dimensions would lead to an increase in market performance in the bank.
\end{abstract}

Keywords: Customer Relationship Management, customer orientation, Customer knowledge Management

DOI: $10.7176 / \mathrm{EJBM} / 14-1-04$

Publication date: January $31^{\text {st }} 2022$

\section{Introduction}

The nature of banking globally has gone through various stages of transformation in service delivery. Traditionally the banks had been predominantly occupied in just cash related activities like accepting deposits, paying cash and opening accounts as well as giving out loans to customers (Adiele, K.C., and Gabriel,J.M., 2013). However in the wake of competition and technological advancements, banks in the world have been more innovative, crafting new ways of reaching out to prospective customers needs and retaining more customers to their base and various strategies have been adopted by banks to increase their share of the market in recent years (Karr, 2012).

The market performance of the banking sector is a function of various variables. According to (Karr, 2012) banks worldwide are putting in measures aimed at improving their market performance. This shows that the use of CRM in the banking sector is being adopted at a global perspective. The banking industry is among the most important sectors of any economy because it acts as a driving force for economic activities and banks occupy a significant place in every nation (Soyibo \& Adekaye, 2011).

In Ethiopia, the banking sector is considered as main beneficiary in recent economic upturn (Tsegay, 2011) and (Shifera, 2011) Therefore, better formation of strategies in banking sector is the most needed one especially in the recent information technology era. Moreover, in Ethiopia, the rapid growth of banking and other financial services provide the financial infrastructure facilities to the economic expansion and structural transformation.

Recently, more than ever before, strong competition, fragmentation of markets, short life cycles of products and low customer awareness and complexity are the big challenges to the banking sector (Tsegay, 2011). In such situation, banks can use the CRM strategy to create, maintain, and enhance strong relationships with their customers to secure their market performance. In addition to that banking sector is a customer oriented services where customer is the main focus. Therefore research is needed in selected banks to understand customer need and their attitude so as to build a long term relationship with banks. Hence this study aims to assess the effect of customer relationship management on marketing performance in the case of selected private banks of Nekemte town, Ethiopia.

\section{Statement of the Problem}

While the use of CRM strategy has grown globally but the use of CRM strategy in Ethiopia has remained consistently low. Yet, even different researchers experiencing contradictory results on the effect of CRM on market performance of banks. For instance, Mithas (2015) found that the use of CRM systems positively impacts customer retention whereas, Boulding,,s ( 2015) found that the application of CRM principles yields positive financial outcomes. To the contrary, Reinartz and Hoyer,,s (2014) found that 70 percent of CRM projects result in either losses or no profit improvements. Therefore the study investigated on the effects of customer relationship management on marketing performance.

In addition to that as the numbers of private banks increases in Ethiopia over a time, banks start to operate in a competitive environment. As increasing the numbers of private banks in Ethiopia banks are competing to attract new customers and they are using CRM as a tool and strategy to attract and retain customers. (Yatish and Ehtesham., 2013) Argued that heavy competition threatening banks revenues and profits. Beside this Cherinet, (2015) stated that as financial market place becomes more dynamic and competitive in Ethiopia, banks also need 
to focus on retaining existing clients through effective relationship Management.. Therefore, undertaking studies about the practice and effectiveness of CRM in Ethiopia banking industry is quite necessary to improve its implementation and practice. Beside this no similar researches done to examine the effect of CRM on market performance in private banks in Nekemte town.

Therefore, CRM organization and knowledge management as customer relationship management dimension in order to discover whether these dimensions has strengthening effect on market performance of the selected private banks in Nekemte town.

\section{Objectives of the study}

To establish the effect of customer relationship management on marketing performance of selected private banks in Nekemte town, Ethiopia

\section{Empirical literature review}

Hamdallah and Evelyn (2011) conducted a research to classify hotels in Ashanti region of Ghana into a category of low, middle, or high customer relationship management conscious. They used both qualitative and quantitative research approaches are employed in their study to get a better understanding of the research issue. The population size of the study is 872 consisting of 1 Star Hotels, 2 Star Hotels, and 3 Star Hotels. The sample size of the study is 142 customer relations officers of hotels in Ashanti region of Ghana. Data is collected mainly from field survey through the use of the questionnaire and yielded $80 \%$ responds rate. The findings suggest that significantly majority of the hotels have low orientation to CRM as a whole.

According to (Sayed, 2011) Sayed exploring the theoretical foundations of customer relationship management and its relationship to the marketing performance from the several perspectives. The population of the research is represented in all the financial institutions working in the Arab Republic of Egypt. They are 197 financial institutions, of which there are 39 banks, 20 insurance companies and 138 brokerage companies The researcher composed a stratified random sample that constitute $50 \%$ of the society. The sample consisted of 20 banks, 10 insurance companies and 69 brokerage companies. There is a significant correlation between marketing performance and focus on the main customers, organizational efficiency and customer knowledge management. (Oghojafor, 2011) explores the question of how IT could enhance firm performance in the areas of customer's service and organization's profitability in the Nigerian insurance industry.

The data used in this study were collected through a survey among insurance companies in Nigeria. The sample was selected from Lagos state, the commercial center of the country. Among the 49 members of the Nigeria insurers Association, 30 companies were selected at random from the directory of members contained in the 2009 Insurance Digest published by the Association. A total of 90 copies of the questionnaire were sent. Eventually, among the 86 copies retrieved, 78 were correctly completed and these were analyzed for this research. The findings show that while most companies have a comprehensive data base of their customers, not all make provisions for their customers to make major transactions online because they have not fully integrated their customer relationship management with information technology.

The findings show that the selected banks apply CRM components but the level of application differs from one bank to another. Cristian and Horatiu (2011) examined the direct outcomes of the CRM activities, as well the relationship among these outcomes and business performance. We used a database containing contacts of 2000 companies. In the end, there were 102 companies who returned questionnaires with answers. 20 of these questionnaires were invalidated, due to missing data or inconsistency. The valid sample had a size of 82 companies, which represent a response rate of $38.86 \%$ based on the number of companies which initially accepted to take part in the survey. The response rate based on the number of contacted companies is $4.1 \%$. The customer-related outcomes (customer retention and loyalty) were found to have a positive relation on business performance.

(Hamid, 2009) Aims to address gap in literature, not only by taking a non-traditional approach of success evaluation; using system's stakeholders ee expectations as an evaluation criteria but also focusing a case study from Pakistan, where ICT industry and specifically CRM is in the initial stages of adoption. Totally, 9 participants were invited to take part in the research study and data was collected over a time period of almost 6 months.

(Rittippant, 2009) Investigated the effectiveness of loyalty card program in the aspect of customer loyalty in the major competitive grocery stores. We distributed and collected 600 questionnaires to gather information from the customers of Big C, Carrefour, and TOPS (200 for each store). All the questionnaires were convenience random sampling with equal amount to both urban and suburban customers with different age, gender, and income level to use as major data in this research to better understand the customers ${ }^{\text {ee }}$ attitude toward loyalty card program of these grocery stores. Moreover, we interviewed three managers of the major grocery chains in order to study more precisely about the effectiveness and the actual result of implementing this program and its benefits from the store ${ }^{\text {ee }}$ perspective. As the results have shown that the loyalty card program has significant positive effect on the customers ${ }^{e e}$ loyalty. Although loyalty card program may not be the best choice for some stores, there also are many other ways to develop and maintain customer loyalty. 
The above studies varied in treating CRM. While some studies treated its humanistic dimension, some treated its technological dimension and some treated its strategic dimension. However, the marketing dimension was of little interest to the studies. The above studies varied in measuring the earnings of CRM. Some studies measured them through the customer's satisfaction and loyalty. Other studies measured them through the return rate on investment. Others measured it through increasing sales and profits. There was less interest in the market share and net profit to net sales. The above studies varied in the results of the effect of the dimensions of CRM on performance. Results showed that some dimensions have effect on performance, and some others have not.

\section{Literature gap}

The above empirical studies reveal different findings for the same variables. So, they lack

Consistency.

Research Hypothesis

Customer orientation, Customer knowledge management ,Technology based CRM ,CRM organization has positive and significant influence on market performance

Source of data

Regarding the data source, the study used both primary and secondary sources.

\section{Research Design}

The researcher has chosen the descriptive and explanatory research design to answer the problem

statement and meet the research objectives on this study.

Data type and sources

The study have been employed both qualitative and quantitative data. The qualitative data includes those data that are primarily collected through interview whereas quantitative data includes objective items through the questionnaires.

\section{Methods of data collection.}

For the purpose of data collection, the researcher used closed-ended questionnaires and structured and semistructured interviews.

\section{Target population}

The target populations of the study were branch managers and employees of the selected private banks. Hence the total numbers of employees in selected banks are,Nib bank nekemte branch 24 employees, Birhan bank nekemte branch 22 employees and oromia international bank nekemte branches 106 employees. so there are 152 employees in selected private banks. Since the number of employee in selected private bank was manageable population the researcher used census technique to distributed questionnaire to employees of selected banks, that means questionnaire were distributed to all 152 employees of the selected private banks.

\section{Method of Data Analysis}

Analysis of data in this research done by using descriptive statistical methods like: frequency, mean, standard deviation and inferential statistical methods such as: correlation and regression.

\section{Model Specification and Description of Study Variables}

Accordingly, the regression equation on the above variables can be stated as follows:

$\mathrm{Y}=\mathrm{X} 0+\mathrm{X} 1(\mathrm{Co})+\mathrm{X} 2(\mathrm{CKM})+\mathrm{X} 3(\mathrm{CRMBT})+\mathrm{X} 4(\mathrm{CRMO})+\mathrm{Ei}$

Where: $\mathrm{Y}=$ market performance.

$\mathrm{CO}=$ Customer orientation.

$\mathrm{CKM}=$ Customer Knowledge management.

CRMBT $=$ CRM Based Technology

$\mathrm{CRMO}=\mathrm{CRM}$ organization

$\mathrm{X} 0=$ the constant parameter.

$\mathrm{X} 1=$ Coefficient of Customer orientation.

$\mathrm{X} 2=$ Coefficient of Customer Knowledge management.

X3 = Coefficient of CRM based Technology

$\mathrm{X} 4=$ Coefficient of CRM organization.

Table 4.14: Descriptive statistics of CRM and Market Performance

\begin{tabular}{|l|l|l|c|}
\hline $\mathbf{N}$ & Variables & Average mean & SD \\
\hline $\mathbf{1}$ & Customer orientation & 3.708 & 1.154 \\
\hline $\mathbf{2}$ & Customer knowledge management & 3.728 & 1.22 \\
\hline $\mathbf{3}$ & CRM based technology & 3.645 & 0.931 \\
\hline $\mathbf{4}$ & CRM organization & 3.693 & 0.9008 \\
\hline $\mathbf{5}$ & Marketing performance & 3.724 & 0.127 \\
\hline
\end{tabular}

Source: own survey 2021, computed in SPSS V. 20 


\section{Model Assumption check}

1 Multi collinearity test

Multi collinearity is tested in this study using the variance inflation factor (VIF) which quantifies the severity of multicollinearity in regression analysis. Multicollinearity occurs when there are high inter correlations among some set of the independent variables. Various recommendations for acceptable levels of VIF have been published on various studies (a value of 10 by Hair, Anderson, \& Black, 1995; \& a value of 5 by Rogerson, 2001 and even 4 by Pan \& Jackso 2008). The rule is that when tolerance value is less than 0.2 and the VIF exceeds 10 ; it is a signal of multicollinearity, which could lead to misleading and/or inaccurate results.

\section{Multicollinearity test}

\begin{tabular}{|l|l|l|}
\hline Variables & Collinearity Statistics \\
\cline { 2 - 3 } & Tolerance & VIF \\
\hline Customer orientation & .377 & 2.656 \\
\hline Customer_knowledgemanagement & .462 & 2.162 \\
\hline CRM-based technology & .561 & 1.783 \\
\hline CRM-organization & .262 & 3.811 \\
\hline
\end{tabular}

a. Dependent Variable: Market performance

Therefore, in this study the tolerance level for all variables is above 0.2 and VIF is less than 10, confirming that the study is free from multi collinearity issue.

$>$ Refer to col linearity Statistics shown above in table 4.16, the tolerance and VIF showed that there was no multi colinearity between the study predictors

\section{Testing for normal distribution of data}

Normality test Multiple regressions assume that variables have normal distributions. This means that the errors between observed and predicted values (i.e., the residuals of the regression) should be normally distributed. This assumption may be checked by looking at a histogram or a Q-Plot. Normality can also be checked with the decision is obtained by looking at the normal probability plots, that is from the points where the data points form a linear pattern, so that it can be considered as consistent with a normal distribution. The result of the tests is presented in the figure below.

\section{Histogram}

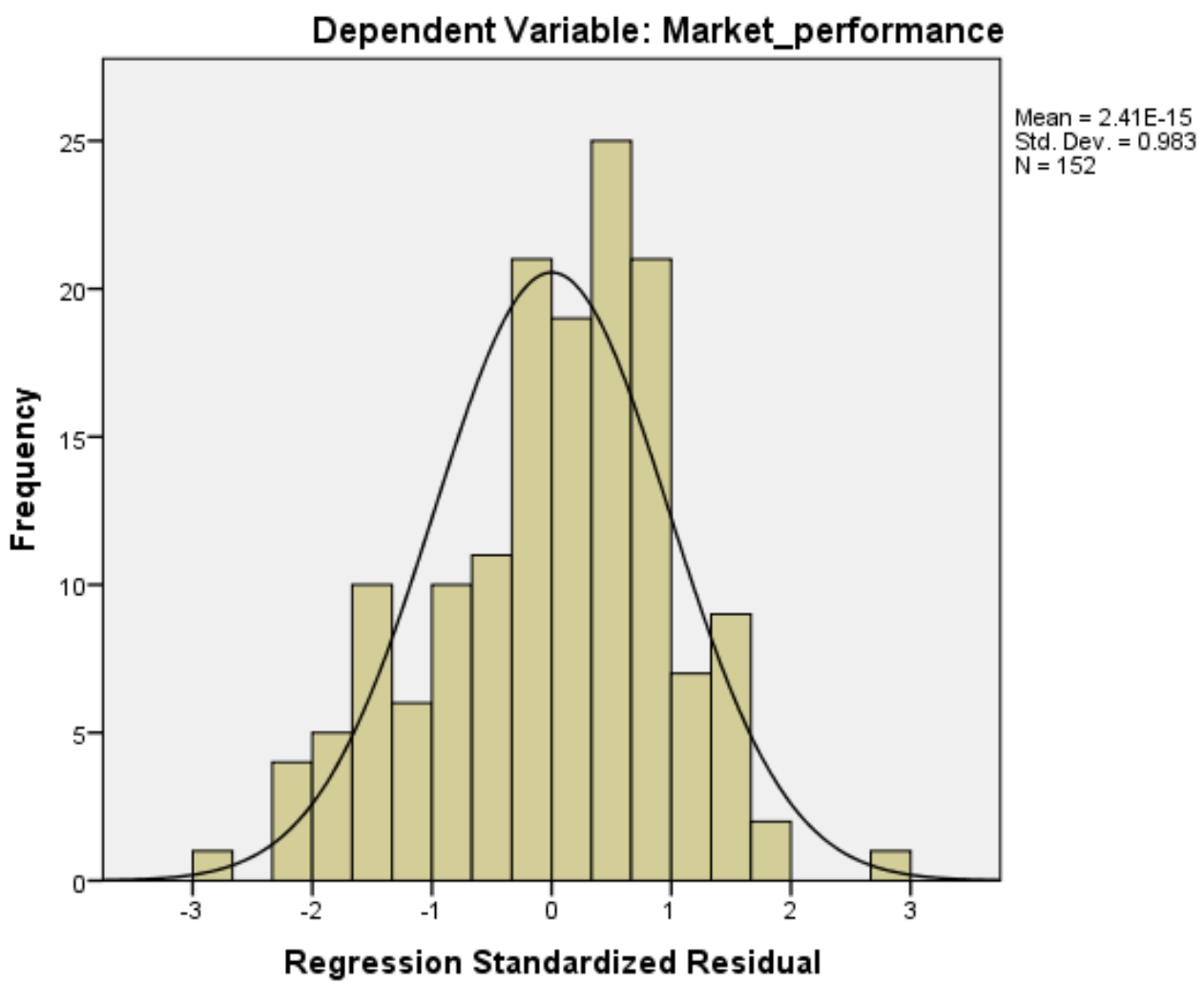

Figure 4.1: Normality test

Source: Own Survey, 2021 


\section{Regression Coefficients}

Table 4.19. Coefficients of customer relationship variables Coefficients $^{\text {a }}$

\begin{tabular}{|c|c|c|c|c|c|}
\hline \multirow[t]{2}{*}{ Model } & \multicolumn{2}{|c|}{$\begin{array}{c}\text { Unstandardized } \\
\text { Coefficients }\end{array}$} & \multirow{2}{*}{$\begin{array}{c}\text { Standardized } \\
\text { Coefficients } \\
\text { Beta }\end{array}$} & \multirow[t]{2}{*}{$\mathrm{t}$} & \multirow[t]{2}{*}{ Sig. } \\
\hline & $\mathrm{B}$ & Std. Error & & & \\
\hline (Constant) & 1.060 & .201 & & 5.270 & .000 \\
\hline Customer orientation & .205 & .073 & .252 & 2.816 & .006 \\
\hline Customer knowledge management & .208 & .067 & .253 & 3.133 & .002 \\
\hline CRM based technology & .122 & .055 & .162 & 2.214 & .028 \\
\hline CRM organization & .194 & .096 & .217 & 2.025 & .045 \\
\hline
\end{tabular}

a. Dependent Variable: market performance

Own Survey ( 2021)

The values of the unstandardized Beta Coefficients indicate the effects of each independent variable on dependent variable. Furthermore, the values of the unstandardized beta Coefficients in the beta column of the Table 4.19 above, indicate which independent variable (CRM dimensions) makes the strongest contribution to explain the dependent variable (market Performance), when the variance explained by all other independent variables in the model is controlled. The sig $(p)$ value indicates whether the independent variable is significantly contributing to the prediction of the dependent variable. The study's hypothesis testing was made based on $\beta$, and $P$ values. Hence using those coefficient results, the proposed hypotheses for this study were tested as follows.

\section{Conclusion and recommendation Conclusion}

The present study examined the effect of customer relationship management on market performance and the research findings indicated that CRM dimensions namely: customer knowledge management, customer orientation, Technology based-CRM and CRM Organization have positive and significant relation with dependent variable Market performance. According to the regression model summary table, R2 value indicated that $55.9 \%$ of the variance on market performance can be predicted by the independent variables. Customer knowledge management is the best predictor as its influence on market performance is greater than others dimensions. It has Positive and significant relation at $\mathrm{p}<0.05$.Beside this customer orientation has positive and significant relation with market performance as $\mathrm{p}$ value of the predictor is less than 0.00 also technology based CRM has has significant relation with market performance. Lastly CRM organization has positive and significant relation with market performance as $\mathrm{p}$ value of the predictor is less than 0.00 .

The previous theories and studies in the area of Customer relationship management showed us that there is a link and positive association between CRM and Market performance. General the study findings support the view point that CRM can enhance profitability and in turn increase market performance.

\section{Recommendation}

It is essential for selected private banks to pay more attention for the CRM dimensions by considering their significant effect on market performance.

\section{Reference}

Abdullateef, A. (2010). The Impact of CRM dimensins on call Center Performance. International Journal of Computer Science and Network Security, 10,No.12, 184-194.

Adiele, K.C., and Gabriel,J.M. (2013). Customer Relationship Management and Bank performance in Nigeria:An Eperical Validation study. International Journal of Science and Research, 1(3):216-423.

Biggam, S. (2008). Succeding with your Masters Dissertation.

Buttle, F. (2009). Customer Relationship Management:Concepts and Technologies 2nd edition Linacre House,jordand Hill,Oxford:Butter worth-Heinemann.

Coltman. (2007). Can superior CRM capabilities improve in banking. Financial service marketing, 12(2), $102-$ 114.

Darrel, R. (2010). Top 10 Management Tools., Http://www.bain.com/management tools.

Dev and Olsen. (2000). Marketing challendes for next decade. 41-47.

Landry, L. (2012). Relationship marketing:hype or here to stay.marketing news. 32(14), 14-27.

Swaminathan. (2004). ) Customer relationship Management: its dimensions and effect on Customer outcomes. Journal of personal selling and sales management, 56(3), 187-196.

Tsegay, M. (2011). The Effect of Customer Relationship Marketing on Customer Rentation in the Banking Sector(A Case Study on Comerical Bank of Ethiopia. 
Yueh. (2010). The Effect of Leadership Styles on Knowledge-based Customer Relationship Management Implementation. International Journal of Management and Marketing Research, 1-19.

Zablah. (2004). An evaluation of divergent perspectives on customer relationship management towards a common uderstanding of an emerging phenomennon. Industrial marketing management, 1333. 